Int. J. Speleol. 14 (1984-1985), pp. 63-68

\title{
Morphological clines in reduced areas. The case of Henrotius jordai (Reitter), cave-dwelling beetle from Majorca Island
}

\author{
Xavier Bellés *
}

SUMMARY

The present paper shows a statistically significant correlation between the geographical latitude and the morphological variation of the pronotum of Henrotius jordai (Reitter) (Col. Caraboidea), cave-dwelling beetle from Majorca island, after studying the linear and curvilinear regression between these two variables.

The existence of specimens situated at different heights of the regression lines leads to the conclusion that morphological variation is clinal.

The phenomenon of "semi-isolation" to which the studied populations are subjected, because of their cavernicolous character, allows to explain the existence of a cline in such a restricted area as that occupied by this beetle (ca. $500 \mathrm{Km}^{2}$ ).

It is worth pointing out the interest in the study of these reduced clines of cavernicolous populations, because they can provide a restricted "observation field" -easier to deal with- to investigate these genetic phenomena and their evolutive implications.

In a preceding note (Bellés, 1976), I dealt with some aspects related to the systematics of Henrotius jordai (Reitter) (Col. Caraboidea), a cave-dwelling beetle spread over an area of ca. 500 $\mathrm{Km}^{2}$, along Serra Nord, in the north-western portion of the Majorca island. In that paper I mentioned that in the caves of Ala-

\footnotetext{
* Centro de Investigación y Desarrollo (C.S.I.C.) c/ Jorge Girona Salgado 18-26, Barcelona - 08034, España.
} 
ró, further to the south, there is a predominance of specimens with the anterior margin of pronotum wider than the posterior one. In the area of Pollença, on the northern side, the ratio becomes even inverse.

This character was one of those used by Jeannel (1950) to diferentiate two species. Later, with the discovery of intermediate locations, both species became united through transition stages (Bellés, l.c.).

These facts have prompted me to study the variation of this character, whether it is gradual and if it can be correlated with geographical factors.

The present work was carried out on a small number of specimens because, Henrotius are normally rare. The results obtained are thus limited as a consequence of the few data available.

\section{STUDY OF THE CORRELATION BETWEEN THE GEOGRAPHICAL LATITUDE AND THE SHAPE OF THE PRONOTUM}

\section{Material and methods}

As all the caves studied lie between 39 and $40^{\circ}$ of North latitude, only the values of minutes and seconds, given in seconds, are reported ("reduced latitude" on Table 1). Most coordinates were obtained from the "Inventario espeleológico de Mallorca" (Encinas et al., 1974).

The change of anterior and posterior margin of the pronotum, was measured by the $I P$ index, defined as the ratio of the lenght of those margins (Fig. 1):

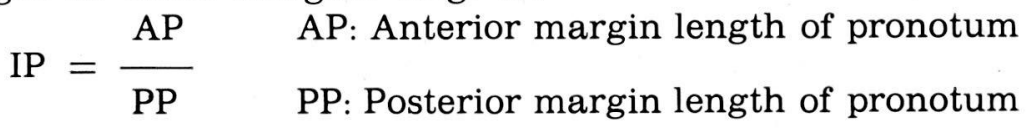

Most IP values on Table 1 are deduced from the corresponding $A P$ and $P P$ values previously reported (Bellés, l.c.). As there is no sexual dimorphism in the pronotum shape, the data include both males and females.

On the other hand, because of the variable number of specimens for each location, the corresponding IP values were averaged.

Definitive calculations were carried out with a Hewlett Packard 9830-A computer. 


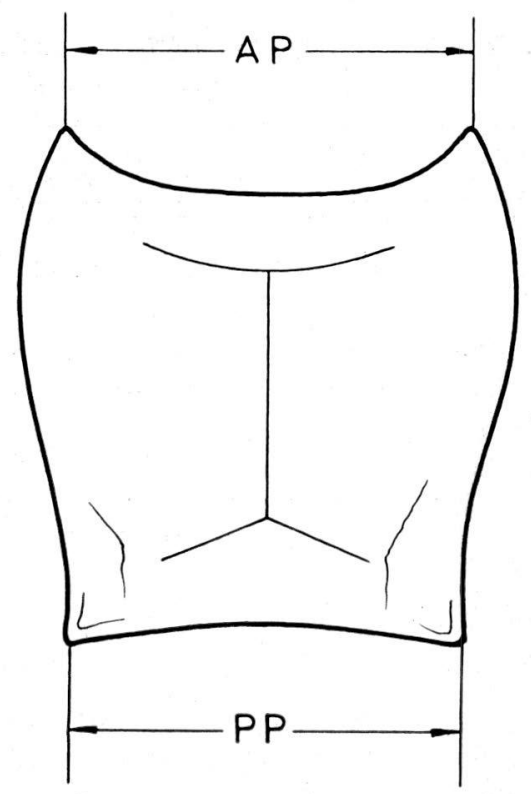

Figure 1 - Pronotum of Henrotius jordai (Reitter), with indication of the measured margins.

Table 1. Pronotum index (IP) and geographical data of the studied samples of Henrotius jordai.

\begin{tabular}{|c|c|c|c|c|}
\hline $\mathrm{N}$ & CAVE & $\begin{array}{l}\text { REDUCED } \\
\text { LATITUDE } \\
(X)\end{array}$ & $\begin{array}{l}\text { SAMPLE } \\
\text { SIZE }\end{array}$ & $\underset{\substack{\text { IP } \\
\text { AVER }}}{\operatorname{AVE}}$ \\
\hline 1 & Av. des Picarol Gros & $2636^{*}$ & 1 우 & 1.100 \\
\hline 2 & Es Bufador de Solleric & 2699 & $50^{\pi}, 39$ & 1.084 \\
\hline 3 & Cv. des Torrent de Cuber & $2760^{* *}$ & 19 & 1.096 \\
\hline 4 & Cv. de Campanet & 2840 & $10^{2}$ & 1.031 \\
\hline 5 & Cv. de Can Sion & 2994 & $60^{2}, 39$ & 1.030 \\
\hline 6 & Cv. de Sa campana & 3044 & $10^{2}, 10+$ & 1.059 \\
\hline 7 & Cv. Argentera & 3172 & 19 & 1.000 \\
\hline 8 & Cv. de Llenaire & 3188 & 10 & 1.000 \\
\hline 9 & Av. de la Malé d'Ariant & 3213 & $10+$ & 0.972 \\
\hline 10 & Cv. de Cornavaques & 3285 & $60^{7}, 49$ & 1.038 \\
\hline 11 & Cv. de Cal Pesso & 3293 & $10^{\pi}$ & 0.970 \\
\hline 12 & Cv. de les Rodes & 3311 & $10^{n}, 1$ 우 & 1.000 \\
\hline
\end{tabular}

* A. Ginés, personal communication

** J. Damians, personal communication 


\section{Results and discussion}

The ccefficients of linear and curvilinear regression (parabola of second degree) were calculated, and the results are shown on Table 2 (values adjusted to four decimals by the computer itself).

The coefficient of determinaticn $\left(R^{2}\right)$ was in the both cases relatively high (it was higher in the case of curvilinear regression). In the case of linear regression, the correlation coefficient (r) was statistically significant at $1 \%$ level.

Figure 2 shows the graphs of the linear regression (dotted line) and curvilinear regression (continuous line), obtained directly from the plotter of the computer.

The present paper demonstrates that the correlation between geographical latitude and pronotum variation is significant (1\%). The pronotum index increases gradually from the northern to the southern specimens. The existence of points in different heights of the regression lines, leads to the conclusion that the morphological variation is clinal, in the sense of Huxley and Haldane (in Margalef, 1974).

It might seem surprising to find a cline in such a reduced area as the present one, but it must be borne in mind that this species is cavernicolous, with all the biasses this implies. It must be admitted that in a population of a given cave, possibilities of migration and genetic interchange with that of another cave -relatively close, at best- are obviously much more limited than in typical epigean populations.

According to Mayr (1942), an important clue to understand the significance of these clines is that usually they are not found in isolated populations. Thus, the present results can be an indirect evidence that the hypogean populations studied are not complete isolated, in other words, not "strictly" cavernicolous.

In summary, this morphological cline could be explaned by two important factors, i.e. reduced gene flow and weak environmental differentiation. These factors are those claimed by Endler (1977) as inducers of steep clines in reduced areas.

Finally, it is worth pointing out the interest in the study of these reduced clines of cavernicolous populations, because they provide a restricted "observation field" -easier to deal withto investigate these genetic phenomena in depth. 
Table 2 - Coefficients of linear and curvilinear regression between geographical latitude and the pronotum index among the studied samples of Henrotius jordai.

\begin{tabular}{|c|c|c|c|}
\hline & & $\begin{array}{c}\text { Curvilinear } \\
\text { Regression } \\
\left(\mathrm{y}=\mathrm{a}+\mathrm{bx}+\mathrm{cx}^{2}\right)\end{array}$ & $\begin{array}{c}\text { Linear } \\
\text { Regression } \\
(y=a+b x)\end{array}$ \\
\hline & a & 2.5226 & 1.5098 \\
\hline Coefficients & $\mathrm{b}$ & -0.0008 & -0.0002 \\
\hline & C & 0.0000 & - \\
\hline $\begin{array}{l}\text { Coefficient of } \\
\text { determination } \\
\text { Regression }\end{array}$ & $\mathrm{R}^{2}$ & 0.7381 & 0.7278 \\
\hline $\begin{array}{l}\text { Kegression } \\
\text { coefficient }\end{array}$ & $\mathrm{r}$ & - & 0.8531 \\
\hline
\end{tabular}

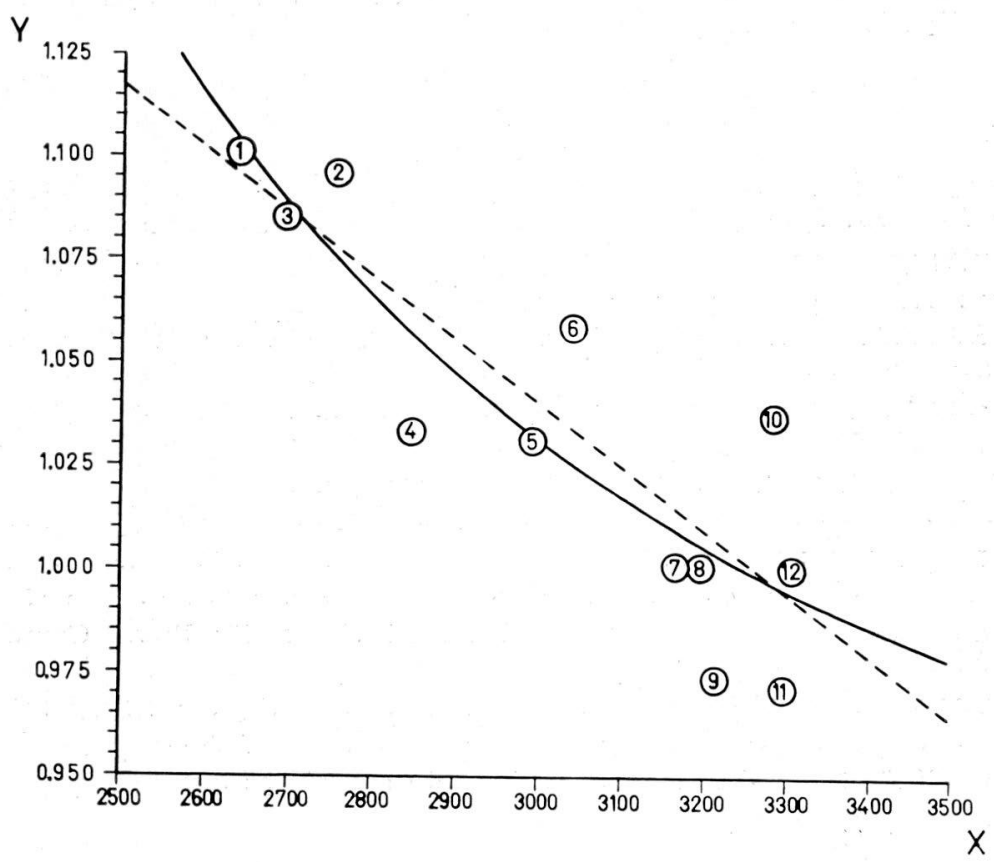

Figure 2 - Relationship between geographical latitude $(\mathrm{X})$ and $I P$ index of the pronotum of Henrotius jordai $(Y)$, for linear (dotted line) and curvilinear (continuous line) regressions. Numbering of points refer to the corresponding population cave as depicted in Table 1. 


\section{ACKNOWLEDGEMENTS}

The author thanks Dr. J. Coll (I.Q.B.O.) and Mr. J.P. Vigo (Instituto the Tecnologia Quimica y Textil, Barcelona) for helpful discussion.

\section{RESUMEN}

En la presente nota se demuestra la correlación significativa entre la latitud geográfica y la variación morfológica del pronoto de Henrotius jordai (Reitter) (Col. Caraboidea), coleóptero cavernícola de la isla de Mallorca, estudiando la regresión curvilínea y lineal entre estas dos variables.

La existencia de ejemplares situados a diversas alturas de las lineas de regresión, hace pensar en una variación morfólogica clinal.

El fenómeno de "semiaislamiento" a que se ven sometidas las poblaciones estudiadas por corresponder a una especie cavernícola, permite explicar el establecimiento de una clina en un área tan reducida como la que ocupa este coleóptero (aprox. $500 \mathrm{Km}^{2}$ ).

Es interesante resaltar el interés del estudio de estas clinas reducidas que corresponden a poblaciones cavernícolas ya que pueden proporcionar un "campo de observación" restringido -y por ello más fácil de abordar- para la investigación de estos fenómenos genéticos y sus implicaciones evolutivas.

\section{LITERATURE}

BELLÉS, X. 1976. Contribución al conocimiento del género Henrotius. Bol. Soc. Hist. Nat. Baleares 21:131-145.

ENCINAS J.A., J. GINÉS y M. TRÍAS 1974. Inventario espeleológico de Mallorca. Bol. Soc. Hist. Nat. Baleares 19:29-49.

ENDLER, J.A. 1977. Geographic variation, speciation, and clines. Monographs in Population Biology, 10. Princeton University Press, Princeton, New Jersey.

JEANNEL, R. 1950. Sur deux Pterostichides de Majorque. Rev. Fr. Ent. 17: $157-165$.

MARGALEF, R. 1974. Ecología. Omega, Barcelona.

MAYR, E. 1942. Systematics and the origin of species. Columbia University Press, New York.

MAYR E., 1976. Geographical character gradients and climatic adaptation, p. 211-217. E. MAYR (Ed.), Evolution and the diversity of life. Selocted essays, Belknap Press of Harvard University Press, Cambridge, Massachussets and London.

PAOLETTI M.G., 1975. Aspetti di cline ed endemismo tra gli atropodi della Vallata Trevigiana, (Vittorio Veneto-Valdobbiadene). Atti 50 Convegno sulla Storia Naturale delle Prealpi Venete, Lago: 115-121.

PREVOSTI A., 1965. Variación geográfica de caracteres quantitativos en poblaciónes británicas de Drosophila suboscura. Genética Ibérica 7 (1-2): $3-44$. 